\title{
ASSOMBRADO E MEDONHO: O OBJETO NA ATMOSFERA GÓTICA DE UM CONTO DE COELHO NETO
}

\author{
HAUNTED AND GHASTLY: THE OBJECT IN THE GOTHIC \\ ATMOSPHERE OF A SHORT STORY BY COELHO NETO
}

\author{
Marisa Martins Gama-Khalil ${ }^{1}$
}

\begin{abstract}
Como as forças sobrenaturais que povoam a sua textualidade, o gótico é fantasmático, permeável e infixo. Aparecido Donizete Rossi - Para uma teoria da desrazão
\end{abstract}

\begin{abstract}
RESUMO: No cotidiano, geralmente consideramos os objetos como meros acessórios com funcionalidades imediatas e dotados de uma inércia característica; contudo a literatura muitas vezes lança uma luz sobre os objetos, delegando a eles uma atuação especial, e, no caso da literatura gótica, essa performance dos objetos aparece com frequência associada ao trabalho com sobrenatural e o terror. Neste ensaio, o corpus de análise eleito é o conto "A bola" do escritor brasileiro Coelho Neto, em função de o objeto não ser destacado apenas pelo título, mas de ele ser a base para toda a trama e para a irrupção da atmosfera gótica. Os fundamentos teóricos são ancorados nos estudos sobre a literatura gótica e a fantástica e nos raros trabalhos sobre a presença e atuação dos objetos na ficção.
\end{abstract}

PALAVRAS-CHAVE: literatura fantástica; literatura gótica; objeto

\begin{abstract}
In everyday life, we generally consider objects as mere accessories with immediate functionality and endowed with a characteristic inertia; however, literature often sheds light on objects, delegating special action to them, and, in the case of Gothic literature, this performance of objects often appears associated to the work with the supernatural and terror. In this essay, the corpus of analysis chosen is the short story "A bola" by the Brazilian writer Coelho Neto, due to the fact that the object is not only highlighted by the title, but because it is the basis for the entire plot and for the eruption of gothic atmosphere. The theoretical foundations are anchored in studies on Gothic and fantastic literature and in rare works on the presence and performance of objects in fiction.
\end{abstract}

KEYWORDS: fantastic literature; gothic literature; object

\footnotetext{
${ }^{1}$ Doutora em Estudos Literários pela UNESP/Araraquara, com pós-doutorado pela Universidade de Coimbra. É professora da UFU, líder do Grupo de Pesquisas em Espacialidades Artísticas (GPEA) e pesquisadora do CNPq com bolsa de Produtividade em Pesquisa. Pesquisa com apoio CNPq.
} 


\section{Considerações iniciais}

O centro das discussões neste ensaio é o conto intitulado "A bola", de Coelho Neto, porque por intermédio dele é que serão deflagradas reflexões acerca de como os objetos podem desempenhar função de relevo em uma narrativa literária. No caso dessa narrativa selecionada, o objeto que estará no ponto central da trama também é responsável por ambientações fantásticas - não explicadas por leis naturais do cotidiano prosaico -, que, por delinearem o horrífico e o sombrio, e engendrarem o medo no protagonista aliam-se a uma motivação gótica de escrita.

Ao trazer o objeto como foco do enredo, o conto de Coelho Neto não figura como uma exceção, pelo contrário, faz parte de uma tradição de histórias que, por meio tramas fantásticas e/ou góticas, coloca em relevo a dicotomia entre sujeitos e objetos. No clássico "O homem da areia", de E.T.A. Hoffmann, por exemplo, a boneca Olímpia ilude o pobre e atormentado Natanael, que se inquieta perante a dúvida instaurada a partir da confusão objeto/sujeito. O conto de Prosper Mérimée "A Vênus de Ille" coloca em seu centro uma estátua que também faz vibrar a incerteza da fronteira entre objeto e sujeito.

\section{Objetos e sujeitos: suas fronteiras e atravessamentos}

A manifestação do modo fantástico, em suas variadas modalidades, categorias ou gêneros afins - como o Gótico -, muitas vezes se elabora por intermédio da figuração de personagens insólitas e monstruosas - como, por exemplo, o fantasma, o vampiro, a bruxa - e isso se deve ao fato de a tradição da narrativa conceber a personagem como o centro das ações. Considera-se que o enredo, como defende Antonio Candido (1972, p. 53), "existe através das personagens", porque elas "vivem no enredo" e, por essa razão, "[e]nredo e personagem exprimem, ligados, os intuitos do romance”. Essa importância da personagem como elemento ficcional também pode ser atestada no campo dos estudos da narrativa fantástica, na medida em que, para alguns autores, é por meio dela que a narrativa pode ser capaz de suscitar a identificação do leitor, conforme assinala o estudioso português Filipe Furtado (1980, p. 84): “a finalidade básica das características atribuídas à personagem é sempre facilitar essa adesão a que se pretende levar o leitor real e que, embora visada por qualquer texto narrativo, desempenha um papel de particular relevo na ficção fantástica”. 
A personagem projeta para o tecido ficcional o sujeito, centro do mundo, senhor das coisas; no entanto as coisas também têm sua importância na configuração das sociedades e, consequentemente, na construção de nossas subjetividades. No livro Nunca fomos humanos: nos rastros do sujeito, organizado por Tomaz Tadeu da Silva, há uma série de indagações e reflexões acerca da aparente supremacia do sujeito nas sociedades. Em um dos ensaios do livro, intitulado "A dobra: psicologia e subjetivação", os autores Miguel Domènech, Francisco Tirado e Lucía Gómez (2001) defendem que os objetos são fundamentais para o processo de subjetivação do sujeito. Para o acontecimento da dobra, responsável pela subjetivação, é imprescindível a relação dos sujeitos não apenas com outros sujeitos, mas também com os objetos. Sabemos que a constituição de nossa subjetividade ocorre movida fundamentalmente pelo "fora"; no fundo somos objetivados a todo momento: pela família, pela escola, pela igreja, pelos grupos com os quais convivemos e por isso nossos discursos, os quais refletem nossa subjetividade, assemelham-se aos discursos dos grupos que se encontram em nosso entorno e que moldam os saberes e os poderes que nos constituem.

A noção de dobra foi empregada por Deleuze para "explicar a possibilidade - lançada por Foucault em seus dois últimos livros - de um si mesmo constituído como núcleo de resistência frente a poderes e saberes estabelecidos" (DOMÈNECH; TIRADO; GÓMEZ, 2001, p. 130). A dobra habita a fronteira entre um lado de dentro e um lado de fora; tais espaços - o dentro e o fora - não são sinônimos de interior e de exterior, porque estes implicam a demarcação de relações baseadas na distinção e nas coibições identitárias, ao passo que na dobra o dentro e o fora se intercambiam. Seguindo os rastros da filosofia do francês Michel Serres, em Atlas, os autores citados defendem que a vida dos homens encontra-se sempre atrelada a objetos e por isso a dobra, responsável por uma subjetivação de si e pela resistência às práticas objetivadoras, acontece sempre na relação com um objeto: "Não se pode falar de processos de subjetivação sem referir-se a dobras, mas não se pode falar de dobras sem referir-se ao objetual” (DOMÈNECH; TIRADO; GÓMEZ, 2001, p.128).

Na literatura, podemos encontrar ficcionalizadas as relações intrínsecas e dialógicas entre objetos e sujeitos; o objeto nem sempre é configurado apenas como elemento subalterno e secundário; algumas vezes ele é alçado à função de aliado nas ações da personagem protagonista e em outras pode assumir, inclusive, a função de protagonista ou antagonista narrativo. Nas narrativas populares ocidentais e orientais, os objetos habitam frequentemente as tramas. Nos contos d'As mil e uma noites, encontramos uma série variada de objetos que de modo amiúde assumem funções mágicas: são tapetes voadores, anéis, lâmpadas mágicas, 
dentre outros, os quais conferem poderes aos seus portadores, possibilitando-lhes aventuras mágicas. Nos contos de fadas e maravilhosos ocidentais a mesma regra se aplica e neles temos uma série bem diversificada de objetos: varinhas de condão, botas de sete léguas, capa invisibilizadora, anéis mágicos, abóboras que se transformam em carruagens, sapatos de cristal, tesouros escondidos e muitas vezes encantados; enfim, são muitas coisas que fogem da ordem do sólito e se delineiam como totalmente insólitas, dando vida e sentido às tramas de tais contos. No campo da mitologia é marcante a presença dos objetos que não só atuam ao lado de personagens, mas as definem e por isso não conseguimos lembrarmo-nos de Netuno sem trazer à mente o seu tridente, ou de Baco sem a sua taça reluzente e repleta de vinho. $\mathrm{Na}$ literatura gótica, há também lugar para a ressignificação dos objetos, como sugere Ariovaldo José Vidal, na "Apresentação" que faz à edição brasileira do romance $O$ Castelo de Otranto da editora Nova Alexandria, ao tratar da ambientação dessa literatura que tem o medo como um dos seus fundamentos estéticos: "O antiquíssimo e arruinado castelo gótico [...] com todas as suas misteriosas salas, quadros que mudam de figura, objetos sinistros, barulhos inexplicáveis" (VIDAL, 1996, p. 8). Os “objetos sinistros" assumem importância nas tramas, algumas vezes como elementos de um cenário soturno e perturbador, outras vezes assumindo a protagonização dessa ambiência perturbadora e medonha, como é o caso do conto aqui escolhido para análise.

Platão, em sua República (1997), vale-se da narrativa lendária do Anel de Giges - um objeto - para formular alguns preceitos filosóficos. Conta a narrativa que o pastor Giges descobriu, depois de um terremoto, uma abertura no solo; entrando nela, viu muitos objetos estranhos, dentre eles um enorme cavalo de bronze oco e, dentro deste, um cadáver com um anel na mão. Giges, ao pegar o anel do cadáver, percebe que ele lhe dá o dom da invisibilidade e, por meio deste, torna-se amante da rainha, assassina o rei e assume o poder. Platão resgata essa narrativa para argumentar sobre a ganância, que se instala na vida dos sujeitos sempre - desde os mais simplórios aos mais arrogantes - e por esse motivo é necessária a Lei: o homem não age com bom senso a não ser que seja obrigado a comportar-se assim. Notemos que a natureza mágica do objeto, que é usual em histórias no mundo todo, é resgatada por Platão, o que nos leva a pensar acerca da potência das coisas para a reflexão sobre a natureza humana, confirmando a tese de Domenèch, Tirado e Gómez anteriormente exposta.

Italo Calvino, em suas Seis propostas para o próximo milênio (1990), começa uma de suas conferências com o relato de uma antiga lenda, na qual se conta que o imperador Carlos 
Magno, já idoso, apaixona-se por uma bela e jovem donzela; contudo ela falece e o imperador manda embalsamar o corpo, ficando extasiado ao lado daquele corpo inerte noite e dia. $\mathrm{O}$ arcebispo, preocupado com aquela obsessão, manda examinar o cadáver e descobre que debaixo da língua da morta havia um anel com uma pedra preciosa. Ele retira o objeto de lá e toma posse dele. Mas, a partir dessa passagem do objeto para as mãos do arcebispo, a paixão de Magno se transfere para ele. O arcebispo, para desfazer-se do anel, lança-o nas águas profundas do lago Constança e, do mesmo modo, a sinistra paixão do imperador se transfere para o lago, ficando ele em suas margens para o resto de seus dias. $\mathrm{Na}$ análise que faz da curta e significativa narrativa, Calvino defende que sempre que um objeto aparece em uma narrativa "ele se carrega de uma força especial, torna-se polo de um campo magnético, o nó de uma rede de correlações invisíveis" (CALVINO, 1990, p. 47). O que seriam essas correlações invisíveis? $\mathrm{Na}$ literatura fantástica, as correlações invisíveis explicam-se pela própria natureza narrativa, que abriga acontecimentos perturbadores de uma ordem cartesiana e cotidiana. Entretanto Italo Calvino, quando trata da magia dos objetos não se refere apenas à literatura fantástica; ele afirma que, quando um objeto é apresentado em uma narrativa, há sempre atrelado a ele um simbolismo mágico de forma implícita ou explícita. Se o objeto já é mágico em uma narrativa não fantástica, em uma história fantástica essa magia tende a avolumar-se e hiperbolizar-se, atingindo um plus ultra (GAMA-KHALIL, 2019). Portador de metáforas várias, esse objeto mágico e/ou perturbador reduplica a possibilidade de sentidos gerados.

Jean Baudrillard notabilizou-se pelos seus estudos acerca da presença marcante das coisas no mundo capitalista, e admite que a sua pesquisa não foi necessariamente movida pela fabricação e pela força de consumo dos objetos, mas pelo "fato de que eles remetiam a um mundo menos real do que poderia fazer crer a aparente onipotência do consumo e do lucro" (BAUDRILLARD, 2001, p. 9-10). Sua pesquisa foi instigada igualmente pela correspondência entre os objetos, bem como pela correspondência deles com os sujeitos: "O objeto designava, então, o mundo real, mas também a sua ausência - e particularmente a ausência do sujeito" (BAUDRILLARD, 2001, p. 11). A relação tão "real", e ao mesmo tempo desprovida de realidade, que existe entre objetos e sujeitos, é a mola propulsora de muitas narrativas fantásticas que têm o objeto como foco protagonizador dos acontecimentos diegéticos. Em seu clássico estudo sobre a literatura fantástica, Tzvetan Todorov também trata das tramas que se desenvolvem em torno de objetos e aborda-os por intermédio de sua relação com os sujeitos: 
Outra consequência do mesmo princípio tem mais extensão ainda: é o apagamento do limite entre sujeito e objeto. O esquema racional nos representa o ser humano como um sujeito que entra em relação com outras pessoas ou com coisas que lhe são exteriores, e que têm um estatuto de objeto. A literatura fantástica abala esta separação abrupta. (TODOROV, 2004, p. 124-125)

Assim, a linha adotada por Todorov para compreender o objeto é a sua correspondência com o sujeito, numa perspectiva similar à de Baudrillard e Domènech, Tirado e Gómez. O teórico búlgaro ressalta com evidência o apagamento do limite entre sujeito e objeto e a consequente transformação do objeto em sujeito, o que fica confirmado através de um dos itens do resumo do capítulo onde ele trata dos objetos: "O objeto torna-se sujeito" (TODOROV, 2004, p. 115). A subjetivação dos objetos nas narrativas fantásticas propicia que eles sejam alçados à condição de protagonistas ou antagonistas do enredo em muitos casos, como poderemos perceber a partir do conto que será analisado neste ensaio: “A bola" de Coelho Neto. Nesses casos, de apagamentos de limites entre sujeitos e objetos - entre o vivo e o inerte, o humano e o inumano - tende-se à criação de uma atmosfera de medo e terror. Diante do terror instaurado no conto, o leitor possivelmente "levantará a sua cabeça" (BARTHES, 2004, p. 26) e a moverá na direção de alguns questionamentos: nossa existência viva, pulsante, contrapõe-se de fato à inércia das coisas que nos rodeiam? Serão de fato elas tão passivas e subjugadas às posições que lhes delegamos?

\section{A bola: um objeto que suscita a ambientação gótica}

A narrativa do escritor maranhense Coelho Neto escolhida como corpus deste ensaio traz um acontecimento que opera uma transgressão nas leis naturais do prosaico, constituindo, dessa forma, uma atmosfera fantástica, e esta se compõe especialmente por intermédio da agregação de recursos característicos ao projeto estético do gótico, conforme veremos ao longo da análise.

Coelho Neto é um dos autores responsáveis pelas experimentações literárias do início do século XX no Brasil. Conforme pontua Carlos Nejar (2011, p. 293), ainda que Octavio de Faria tenha trabalhado pela valorização da obra desse escritor, esta continua praticamente silenciada por parte da crítica. Nejar assevera também que, muito mais do que elaborador de personagens, Coelho Neto desenha-se em suas narrativas como um exímio construtor de ambientes. Como leitora de sua obra, é possível observar que nessas pinturas espaciais e 
ambientais fica evidenciada a sua habilidade com a imaginação - descortinando universos insondáveis - e com a atmosfera soturna, interna e externa às personagens.

O conto de Coelho Neto em tela neste ensaio narra uma história ocorrida nos primeiros anos do século XX, mais especificamente em 1904, e tem como protagonista inicial um escritor, o qual, assumindo a função de narrador, conta que chegou no referido ano na cidade de Campinas e se instalou juntamente com a sua família no Hotel Metrópole, local onde ocorrem os acontecimentos assombrosos envolvendo um objeto, uma bola com a qual presenteara um dos seus filhos.

Ele trabalhava em um grande salão desocupado que havia no hotel; a dimensão enorme do cômodo, descrito por ele logo no início do enredo, parece hiperbolizar-se em função de haver nesse espaço quase nenhuma mobília e por isso a descrição da mesa na qual trabalhava escrevendo é representada como "uma pequena ilha em pleno oceano" (COELHO NETO, 2011, p. 73) ${ }^{2}$. Descreve também a situação financeira precária de sua família, bem como a fragilidade física, pois ele, a mulher e os filhos eram acometidos por enfermidades diversas, e, como resultado dessa situação, caracteriza como "sombrios" (p. 73) os dias daquela sua difícil existência. O adjetivo "sombrios" prepara o leitor para os eventos que estão por vir, e o envolve, desde já, em um clima "soturno", vocábulo que será posteriormente usado pelo narrador. Essa caracterização "sombria" é bastante característica da ambientação gótica, porque boa parte do medo, efeito comum relacionado a essa ambientação, irrompe por meio da composição de um espaço/cenário sombrio, de um locus horribilis. Sombria é a sua vida - repleta de males e misérias - e igualmente sombrio é o espaço em que se encontra. $\mathrm{O}$ sombrio referente ao "dentro" e ao "fora" da personagem mobiliza e destaca na narração a perturbadora relação do sujeito com as coisas em seu entorno.

Para preencher as noites de insônia, o narrador protagonista dedicava-se a escrever em sua mesa insular, "divagando e compondo, ao léu do sonho, distrairia o espírito, deixando-o solto na fantasia, a correr mundos encantados" (p. 74). Pode-se perceber, no trecho que antecede o início dos acontecimentos fantásticos que irão irromper, que a ambientação é favorável à distração do espírito, à entrada de eventos assombrosos e sobrenaturais, os quais desencadearão fortes sentimentos relacionados ao medo e ao terror. A solidão do narrador, na labuta de escrita pelas noites adentro, contribui para a instauração do gótico: "a solidão [...] leva a interpretações errôneas ou exacerbadas e a impressões fortes, a loucura do absorver-se

\footnotetext{
${ }^{2}$ Como todos os trechos transcritos do conto são do mesmo autor - Coelho Neto - e têm a mesma data de edição, só será exposta, na referência de citação, a partir daqui, o número da página.
} 
em si mesmo, a corrupção ou a degradação do espírito e da mente” (ZANINI, 2017, p. 57). O narrador do conto de Coelho Neto, imerso em sua solidão, experimentará um acontecimento que colocará em dúvida a sua capacidade de interpretar racionalmente o mundo ao seu redor.

Se a solidão do espaço sombrio e frio do cômodo vazio de mobílias contribui para a entrada do narrador em uma atmosfera insólita, a temporalidade igualmente coopera para tal ambientação, porque quando o acontecimento metaempírico emerge, é noite. Antes de relatar o que lhe acontecera, o narrador antecipa com destaque as percepções e os sentimentos que foram decorrência daquilo que ele iria ainda narrar: "Foi em uma dessas noites que, pela primeira vez, senti o sangue regelar-se-me, as carnes crisparem-se-me, arrepiarem-se-me os cabelos de pavor" (p. 75). Narra, dessarte, primeiro os efeitos e depois a causa. A escolha por esse modo de narrar busca provocar no leitor o efeito do suspense, que provavelmente já passa a esperar que ocorram eventos fora da ordem da normalidade, fatos possivelmente repletos de terror. A experiência dessas sensações é reverberada em ações no corpo, o terror concretiza-se no corpo: o sangue regela, as carnes crispam e os cabelos arrepiam. Essas ações corporais repercutem o medo, porque foram instigadas pela sensação de perigo, o perigo de não compreender o porquê de um objeto extrapolar sua inércia habitual. $\mathrm{O}$ terror, conforme Edmund Burke (2017) pontua em suas teses sobre o sublime, relaciona-se ao assombro e à admiração, por esse motivo as reações corporais afloram rapidamente a partir do impacto de um acontecimento inexplicável.

Pelo trecho do conto anteriormente transcrito pode-se perceber que aquilo que será narrado ocorreu durante a noite, temporalidade propícia como cenário da irrupção do sobrenatural em narrativas góticas, uma vez que a escuridão, o arrefecimento da luz, "diminui a chama dos 'redutores' da atividade imaginativa" (DELUMEAU, 2007, p. 43). A atividade imaginativa já se encontrava aflorada em função de o escritor encontrar-se em meio ao mundo encantado da escrita e, sendo reduzida com o escuro, tende a aumentar. Em nossa cultura, o escuro está quase sempre atrelado ao medo, conforme esclarece Jean Delumeau:

Os textos bíblicos clássicos, durante muito tempo, conjugaram seus efeitos para induzir nas almas o medo da noite. Cícero inclui entre os filhos da noite o medo, [...] a velhice e o desgosto. A simbologia cristã associa o mal à sombra e faz de Satã o soberano do império das trevas. Nash também declara que a noite é o livro negro do diabo no qual se inscrevem nossos pecados (2007, p. 44).

Pelo fato de a noite ser associada ao mal, Edmund Burke (2017) acredita que a obscuridade é imperativa para tornar um objeto terrível; ela coopera para o pavor 
experimentado pelo leitor. Na ambientação noturna, materializada pela obscuridade, o narrador do conto relata que um "estampido seco que partia de um dos ângulos da sala" (p. 75) retirou sua atenção, que até o momento estava posta no trabalho da escrita. Quando voltou seu olhar para o local de onde partira o ruído, viu com espanto, “descendo lentamente pelo assoalho, uma bola branca, de celuloide" (p. 75), que ele dera de presente para um dos filhos. O fato de ela ser branca e movimentar-se sozinha aproxima-a de um efeito fantasmático. Ele estranha, obviamente, o fato de a bola mover-se sozinha, mas procura inibir o estranhamento e o medo por meio de suposições baseadas em um pensamento racional: a bola fazia aquele barulho medonho porque dentro dela havia um grão de chumbo; quanto ao estranho fato de ela rolar, atribuiu à obra de ratos, que a fizeram deslizar pelo declive do assoalho, indo parar bem perto da cadeira onde ele encontrava-se.

Essa tentativa de racionalização é muito frequente nos contos fantásticos. Um acontecimento que pode ser explicado por intermédio de causas naturais ou sobrenaturais e a hesitação entre essas duas causas cria o efeito sobrenatural. Todorov (2004, p. 36) elucida: ““Cheguei quase a acreditar': eis a fórmula que resume o espírito do fantástico. A fé absoluta como a incredulidade total nos levam para fora do fantástico; é a hesitação que lhe dá vida". Em "A bola", o narrador hesita e vale-se da racionalização do acontecimento, buscando causas naturais para atenuar o imenso "pavor" (p. 75) que toma conta dele, porque notemos que ele já afirmara que o seu sangue regelou, suas carnes crisparam-se e seus cabelos arrepiaram-se, ou seja, a explicação que ele procura para justificar naturalmente aquilo que se afigura como sobrenatural é um mecanismo de defesa a esse seu estado de pavor.

Em muitos casos o medo aparece governado pelo "jogo de contrários", como explica Jacques Rancière (2007, p. 63), como a tensão entre o esperado e o inesperado ou "a relação do que cada um sabe sobre o outro, o que este ignora". Ocorre sempre um jogo entre o conhecido e o desconhecido, entre o sólito e o insólito. No conto de Coelho Neto, o movimento da bola pelo aposento gera o jogo de contrários, e a consequente oscilação entre o natural e o sobrenatural. O jogo de contrários adquire maior tensão em função de a narrativa elaborar-se por meio de uma perspectiva do fantástico, à maneira todoroviana, gerando a hesitação. Tal jogo desencadeia igualmente o desenho definido de uma atmosfera gótica na narrativa, em função de nela haver uma espécie de retórica do medo: todo o discurso do narrador planteia paulatinamente, através das descrições e dos vazios - que geram aberturas e suspense -, uma atmosfera de terror. 
Com a racionalização do insólito, o escritor volta ao seu trabalho, entretanto logo a bola o interromperá novamente. Ela volta a rolar e retorna para o lugar de onde ela saíra. Agora, porém, não cabem explicações, já que elas não se aplicam sob uma ótica da lógica: "Se, como eu me explicara, ela viera pela inclinação do soalho, como assim remontava vencendo o aclive? Se descera impelida por algum rato, que força a fazia voltar, e direta, ao sítio de onde se deslocara levada por atração magnética?” (p. 75). A partir desse momento, então, não há como explicar o inexplicável. Ou há? Seria projeção apenas da solidão do narrador que o levara a pesadelos soturnos?

A bola passa a ser o centro da narração, dividindo a função de personagem com o escritor, o qual, a partir do momento em que não consegue explicar o acontecimento, deixa-se tomar pelo terror. Portanto, a bola alça-se à condição de persona narrativa, uma vez que ela assume uma função muito comum às personagens - a ação. Na condição de persona a bola passa a ser antagonista. Ela, ao centro, e ele, escritor, observador aterrorizado pela cena sobrenatural provocada por um aparentemente simples objeto. As suas sensações passam a figurar em seu relato, ocupando o ponto central da narrativa:

Acompanhei-a com o olhar pávido e sentia-me enregelar, transido. Os olhos ardiamme fitos no estranho objeto que se movia animado, que se dirigia, conscientemente, em rumo direto, sem o menor desvio e, chegando ao ângulo de onde partira ali se encravou e ficou. (p. 75)

No trecho transcrito, posterior ao movimento da bola de volta ao lugar de onde partira, o narrador descreve seu estado de terror com impressões sensoriais visuais e táteis: os olhos cheios de pavor (olhar pávido), a sensação de frio, gelo, e por fim, resume tudo com o vocábulo "transido", que remete a uma circunstância de dominação pelo pavor, pelo pânico. Todo esse medo do sujeito provocado por um objeto é desenhado pela retórica do narrador em um movimento crescente, bem aos moldes de uma ambientação gótica. A partir do movimento da bola ao lugar de origem é a condição de narrador observador aterrorizado que vai predominar e tal condição é atestada pela repetição de vocábulos relacionados à visão "olhar pávido"; "Os olhos ardiam-me fitos" -, vocábulos esses que sugerem igualmente uma ponte lançada entre ele, o narrador, e os possíveis leitores diante de fato tão inexplicável, insólito e assombrado.

Como esclarece Noël Carroll, as narrativas que têm o medo como base suscitam o afeto: "os gêneros do suspense, mistério e horror derivam seus próprios nomes dos afetos (affects) que pretendem provocar - um sentimento do suspense, um sentimento do mistério e 
um sentimento do horror" (CARROLL, 1999, p. 30). E é o que temos no conto de Coelho Neto desde o momento em que um simples objeto decide romper com o modus operandi esperado por uma coisa, por uma bola. Seria ilusão dos sentidos? O fato aparentemente tão simples - o movimento da bola - não pode ser explicado pelas leis da física, através de uma tese pautada na lógica, originando, pois, o insólito, o que não costumar acontecer, desencadeando como resultado o acontecimento fantasmático e aterrorizador. $\mathrm{O}$ uso do vocábulo fantasmático aqui aponta tanto para o sentido do ilusório como para o fato de a bola branca, na ambientação noturna, assemelhar-se a um fantasma. Uma bola espectral.

Seguindo os estudos de Filipe Furtado, podemos caracterizar essa bola como um objeto metaempírico, porque, para esse pesquisador português, a fenomenologia metaempírica abarca elementos e eventos que se encontram "para além do que é verificável ou cognoscível a partir da experiência, tanto por intermédio dos sentidos ou das potencialidades cognitivas da mente humana, como através de quaisquer aparelhos que auxiliem, desenvolvam ou supram essas faculdades" (FURTADO, 1980, p. 20). A bola, conforme aparece figurada no conto em tela, não pode ser explicada pelas bases de nosso atual entendimento cognoscível, na medida em que uma bola, prosaicamente, não tem movimentação própria, ela necessita de um sujeito que a mova, acionando seu movimento.

Na sequência do conto, o narrador prossegue dando relevo à descrição de suas afecções em relação à movimentação da bola:

A sala encheu-se de soturno ressoo como de concha e em tal zoada o meu pavor crescia tolhendo-me em paralisia gélida. A chama do gás tremia tornando-se de livro funéreo. E meus olhos, por mais que eu os quisesse arredar, prendiam-se irresistivelmente à bola, que se imobilizara no canto da casa, como fera acuada que preparasse novo bote. (p. 76)

A representação da sala coaduna-se à atmosfera de medo e terror experimentada pela personagem. Nesse caso, o narrador nos remete a uma sensação auditiva: um "soturno ressoo como de concha”, o que é coerente com o espaço do aposento: muito grande e ocupado por poucos móveis, gerando uma sombria e perturbadora sensação auditiva de eco, similar ao de uma concha. Lembremo-nos também de que o som da concha parece evocar uma outra dimensão diferente daquela vivida por nós em nosso mundo prosaico, situação muito similar à do conto.

E, mais uma vez, nesse último trecho citado, a descrição confere importância às reações emocionais e corpóreas do escritor, dando realce aos efeitos provocados pelo medo: o 
"pavor" e a sensação de frio em sua carne, provocando uma "paralisia gélida"; ambos - o pavor e o enregelar-se - são recorrentes e aparecem agora pela terceira vez, reiterando as sensações vividas pelo escritor. Os olhos dele se prendem ao objeto causador de seu pavor, paralisam-se em cima da bola que, naquele momento, encontra-se paralisada em um canto.

Todo esse trabalho com as reações emocionais da personagem tem muito sentido em um conto cuja mola propulsora é o medo, como apontado por Noël Carroll, em seu estudo sobre a filosofia do horror. Ainda que o referido estudo se dirija às narrativas fílmicas, as reflexões de Carroll são muito válidas e coerentes para as narrativas literárias. Carroll defende que as reações emocionais das personagens fornecem subsídios, instruções, sobre como o espectador/leitor pode comportar-se diante dos fatos sobrenaturais que emergem durante a narrativa. Costuma haver um sincronismo de sensações das personagens com as dos leitores, dando origem ao "efeito de espelho": "as emoções dos personagens e as do público estão sincronizadas em certos aspectos importantes, como podemos facilmente observar numa matinê de domingo no cinema do bairro" (CARROLL, 1999, p. 34). No conto de Coelho Neto, as reações emocionais do escritor são descritas à exaustão, como que a assinalar essa possível identificação dos leitores e uma provável adesão ao efeito de espelho.

$\mathrm{Na}$ sequência do conto, após o escritor encurralar-se e paralisar-se diante da paralisação da bola, com medo de que essa imobilidade fosse a fase preparatória para o bote o pulo da bola sobre ele -, o escritor recua, decidindo abandonar a sala sombria e a bola ameaçadora; dirige-se para o quarto sem ao menos apagar o gás. No seu quarto, o medo ainda faz com ele tenha visões: "Estrias fulguras lampejavam nos espelhos. Todo eu vibrava estarrecidamente. Quis, entretanto, reagir, tornar à sala, desafiar o sobrenatural; faltou-me ânimo" (p. 76). Tais visões são provocadas pelo medo e projetadas exatamente sobre um objeto inquietante e muitas vezes relacionado a fatos metaempíricos, o espelho. Acuado, verbaliza como define aquela bola e a situação gerada por ela: "sobrenatural", externando, pois, a palavra que define a trama que narrara.

Contudo toda a atmosfera sobrenatural esvanece com um som de vida: o choro de sua filha, som que age como uma espécie de "exorcismo" para aquela "lúgubre quietação rondada pela Morte" (p. 76). Após o choro da filha, consegue dormir e, ao acordar, vai até a sala e percebe estarrecido e amedrontado: "a bola que eu deixara encurralada no ângulo da sala, achava-se debaixo da minha cadeira". O conto se encerra nesse momento, reforçando o recurso do "indescritível” (CARROLL, 1999), tão comum em narrativas de terror, uma vez que não há uma solução para o assombramento; há, sim, uma abertura enorme para o leitor 
interpretar e realizar conjecturas: o que acontecerá depois? A bola continuará aterrorizando o escritor? Qual o motivo do caráter assombrado e medonho de uma simples bola de brinquedo? Qual seria de fato a relação do objeto sinistro com o escritor solitário? Ela representaria a dobra desse sujeito? Sua condição material medonha e espectral? Essa abertura tão comum em narrativas de terror figura igualmente como a marca da literatura fantástica na visão de Julio Cortázar (2006, p. 178): “[n]ão há fantástico fechado, porque o que dele conseguimos conhecer é sempre uma parte e por isso o julgamos fantástico". A indefinição e o indescritível instigados pela abertura são responsáveis por construir imaginariamente uma atmosfera de medo e contribuir para a sugestão do gótico.

Conforme pontua Fernando Monteiro de Barros (2016, p. 2475) com base nas ideias de Camille Paglia, o alto gótico psicológico é "abstrato e cerimonioso"; ao contrário do gótico que se fundamenta no grotesco, não há a carnificina ou o horror. Nesse conto, o que ocorre de medonho é o movimento de uma bola, que, conforme já pontuamos, em uma situação prosaica, precisa de um impulso externo para movimentar-se; entretanto a bola, contrariando as leis naturais, movimenta-se de um lado a outro, como vimos, conseguindo aterrorizar o escritor, enfeixando-o em um espaço minúsculo imaginário - o espaço criado pelo medo que invade sua mente e seu corpo. Temos, pois, no conto o gótico psicológico, o qual age de modo lento, mas avassalador. Trata-se do terror, que é o nível mais acurado de trabalho com o medo, ocorrendo por meio da sugestão e atuando, por isso, psicologicamente (KING, 2006), como acontece no conto, uma vez que o protagonista tenta inclusive atribuir explicações racionais para o acontecimento, laborando em sua mente conjecturas, porém sofrendo também a pressão do medo de que suas conjecturas racionais não se sustentem.

É possível verificar no conto toda uma construção que se pauta por uma "psicologia do medo" (ROSSI, 2008), que aparece configurado por intermédio de elementos que atravessam o conto, como a escuridão e a obscuridade, a irrupção de um acontecimento metaempírico ou sobrenatural, o mal instalado possivelmente nesse acontecimento, e a reverberação do medo e do terror. Esse conjunto propiciado e construído pela psicologia do medo esboça com tons obscuros uma atmosfera gótica.

O conto de Coelho Neto, escrito nos primeiros anos do século XX, assemelha-se muito a uma parte da narrativa do filme de Peter Medak, intitulado The changeling (1980), foco de uma das reflexões de David Roas (2011) sobre a afinidade entre o medo e o fantástico. A semelhança entre o conto de Coelho Neto e o filme de Medak ocorre em decorrência da presença de uma bola que se move sozinha. No caso do filme de Medak, a bola aterroriza o 
compositor John Russel, que, traumatizado com a morte trágica da esposa e da filha, decide isolar-se, alugando uma estranha casa, mal assombrada. Nessa casa, ele, enquanto tenta trabalhar, entra em contato com manifestações sobrenaturais, uma delas é com uma pequena bola, que, durante uma das noites desce lentamente por uma enorme escada. Aterrorizado, o escritor pega a bola, entra em um carro e, ao cruzar uma ponte, joga a bola no rio. Contudo o sobrenatural não o abandona: "Entonces, regresa a casa. Y al entrar, ve como la pelotita cae rodando de nuevo por la escalera ... mojada" (ROAS, 2011, p. 85).

Rosalba Campra (2016, p. 48) defende que "a multiplicidade de predicados ou qualidades irredutíveis que se manifestam em um conto fantástico pode se limitar as três eixos opositivos fundamentais [...]: concreto/não concreto; animado/inanimado; humano/não humano". O trabalho com o fantástico no conto de Coelho Neto que tem uma ambientação gótica ocorre por intermédio do trabalho com os dois últimos eixos. O animado é compreendido como aquilo que é "dotado de movimento, vontade, tendência" (CAMPRA, 2016, p. 51) e o inanimado refere-se a toda matéria inerte. Conforme já pontuamos, a bola objeto -, prosaicamente, só se movimenta com a ação de um sujeito; contudo, no conto de Coelho Neto, ela adquire movimento sozinha. De certa forma, "a passagem do inanimado ao animado se sobrepõe ao eixo substantivo da identidade" (CAMPRA, 2016, p. 60), sugerindo que naquela bola se escondesse um "resíduo do eu", de uma subjetividade, de uma humanidade. Por isso o eixo animado/inanimado é muito próximo do humano/não humano.

\section{Considerações finais}

Ao longo da análise, foi possível demonstrar como essa narrativa fantástica tem, no centro de sua construção, recursos e elementos estéticos que se relacionam à ficção gótica, que pode ser definida como a arte "que dá continuidade a uma prática primordial do homem: usar a faculdade da imaginação para produzir narrativas que nos ajudem a lidar com o nosso assombro diante do mundo que nos cerca" (FRANÇA, 2018, p. 88). No caso do conto, todo esse assombro e a reflexão dele resultante surge propiciada por uma bola de brinquedo. Há uma tradição de outras narrativas cujo objeto de terror é um brinquedo, como a medonha Anabelle do filme dirigido por John R. Leonetti, ou como o Brinquedo assassino, filme dirigido por Tom Holland. A bola do conto de Coelho Neto faz reverberar sentidos descontínuos e perturbadores, bem na linha de entendimento do terceiro nível de sentido de 
que fala Roland Barthes (1990), o sentido obtuso, que é desviante e esquivo, daí o grau de perturbação que tende a provocar.

O objeto, no conto de Coelho Neto, atrai para si o foco da trama; é ele o responsável pela instauração de uma ambientação gótica - por meio de uma psicologia do medo -, definindo, portanto, a configuração estética da narrativa. Há uma personagem humana que figura como protagonista e que se aterroriza com os acontecimentos insólitos e sobrenaturais; entretanto sem a bola o enredo assombroso não existiria; sem ela, a personagem protagonista não sentiria medo e terror. Aliás, como vimos, a bola divide com o escritor a função de personagem, atuando como uma antagonista, colocando-se, inclusive, num plano superior ao dele, porque sem a bola, o enredo não teria sentido, seria apenas a história de um escritor escrevendo suas novelas e crônicas em um aposento de um hotel situado em Campinas. Nesse sentido, é possível afirmar que a tese de Candido tem suas exceções, porque, nesse caso do conto de Coelho Neto, o enredo não existe sem o objeto, ainda que, para tanto, ele precise reverberar-se com efeitos de humanidade - melhor dizendo: de uma humanidade fantasmática.

\section{REFERÊNCIAS}

BARROS, Fernando Monteiro de. A alegoria e o fantasma no Gótico brasileiro: Cornélio Penna e Lúcio Cardoso. Anais do XV Encontro ABRALIC. Rio de Janeiro: UERJ, 2016, p. 2472-2482. Disponível em: http://www.abralic.org.br/anais/arquivos/2016_1490918496.pdf Acesso em: 25 de jul. de 2020.

BARTHES, Roland. O rumor da língua. São Paulo: Martins Fontes, 2004.

BARTHES, Roland. O óbvio e o obtuso. Rio de Janeiro: Nova Fronteira, 1990.

BAUDRILLARD, Jean. Senhas. Rio de Janeiro: Difel, 2001.

BURKE, Edmund. Investigações filosóficas (Fragmentos). FRANÇA, Julio; ARAUJO, Ana Paula. As artes do mal: textos seminais. Rio de Janeiro: Bonecker, 2017.

CALVINO, Italo. Seis propostas para o próximo milênio. São Paulo: Companhia das Letras, 1990.

CAMPRA, Rosalba. Territórios da ficção fantástica. Rio de Janeiro: Dialogarts, 2016.

CANDIDO, Antonio. A personagem do romance. In: CANDIDO, Antonio. et al. A personagem de ficção. São Paulo: Perspectiva, 1972. p. 53-80.

CARROLL, Noël. A filosofia do horror: ou paradoxos do coração. Campinas: Papirus, 1999. 
COELHO NETO. "A bola”. In: BATALHA, Maria Cristina (Org.). O fantástico brasileiro: contos esquecidos. Rio de Janeiro: Caetés, 2011. p.73-76.

CORTÁZAR, Julio. Valise de cronópio. São Paulo: Perspectiva, 2006.

DELUMEAU, Jean. Medos de ontem e de hoje. In: NOVAES, Adauto. Ensaios sobre o medo. São Paulo: Ed. Senac São Paulo; Edições Sesc SP, 2007. p. 39-52.

DOMÈNECH, Michel; TIRADO, Francisco; GÓMEZ, Lucía. A dobra: psicologia e subjetivação. In: SILVA, Tomaz Tadeu da (Org. e Trad.). Nunca fomos humanos: nos rastros do sujeito. Belo Horizonte: Autêntica, 2001. p. 111-136.

FRANÇA, Julio. Das formas de narrar o medo ao gótico: como o horror na arte tornou-se a arte do horror. In: GAMA-KHALIL, Marisa Martins; SANTOS, Jamille da Silva (org.). Nos labirintos do medo: estudos sobre o medo na ficção. Rio de Janeiro: Bonecker; Dialogarts, 2018. p. $72-89$.

FURTADO, Filipe. A construção do fantástico na narrativa. Lisboa: Livros Horizonte, 1980.

GAMA-KHALIL, Marisa Martins. O discurso e a diegese do fantástico: o plus ultra da singularização. In: SANTOS, Luciane Alves; GABRIEL, Maria Alice; DANTAS, Michelle Santos. Reflexões sobre o insólito ficcional. João Pessoa: Editora UFPB, 2019.

KING, Stephen. Danse macabre. London: Hodder \& Stoughton, 2006.

NEJAR, Carlos. História da literatura brasileira: da Carta de Caminha aos contemporâneos. São Paulo: Leya, 2011.

PLATÃO. A República. São Paulo: Nova Cultural, 1997.

RANCIÈRE, Jacques. Do medo ao terror. In: NOVAES, Adauto. Ensaios sobre o medo. São Paulo: Ed. Senac São Paulo; Edições Sesc SP, 2007, p. 53-71.

ROAS, David. Tras los límites de lo real: uma definición de lo fantástico. Madrid: Páginas de Espuma, 2011.

ROSSI, Aparecido Donizete. Manifestações e configurações do Gótico nas literatura inglesa e norte-americana: um panorama. Ícone - Revista de Letras, São Luís de Montes Belos, v. 2, p. 55-76, jul. 2008.

ROSSI, Aparecido Donizete. Para uma teoria da desrazão. In: ESTEVES, Antonio R.; RAPUCCI, Cleide A. Vertentes do insólito e do fantástico: leituras. Rio de Janeiro: Dialogarts, 2017. p. 77-92.

TODOROV, Tzvetan. Introdução à literatura fantástica. Tradução de Maria Clara Correa Castello. São Paulo: Perspectiva, 2004.

VIDAL, Ariovaldo José. Apresentação. In: WALPOLE, H. O castelo de Otranto. São Paulo: Nova Alexandria, 1996. p. 8-10. 
ZANINI Claudio. Da pedagogia desumanizadora ou o que Palahniuk aprendeu com Sade. In: FRANÇA, Julio; COLUCCI, Luciana. As nuances do gótico. Rio de Janeiro: Bonecker, 2017. p. 47-68.

Recebido em 01/10/2020.

Aceito em 07/12/2020. 